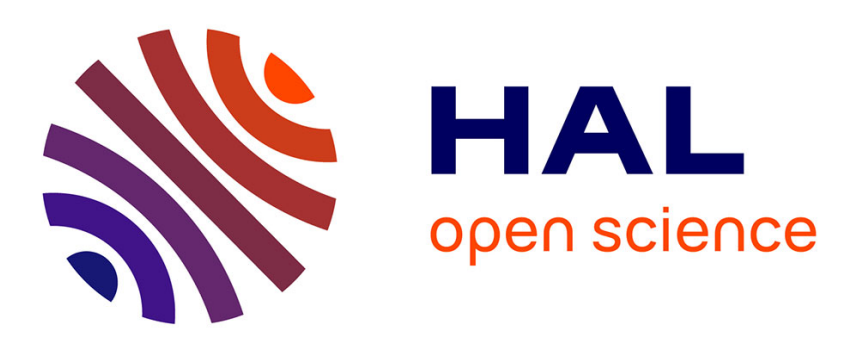

\title{
Nucleation of Brushite and Hydroxyapatite from Amorphous Calcium Phosphate Phases Revealed by Dynamic in situ Raman Spectroscopy
}

\author{
German Montes-Hernandez
}

\section{- To cite this version:}

German Montes-Hernandez. Nucleation of Brushite and Hydroxyapatite from Amorphous Calcium Phosphate Phases Revealed by Dynamic in situ Raman Spectroscopy. Journal of Physical Chemistry C, 2020, 124 (28), pp.15302-15311. 10.1021/acs.jpcc.0c04028 . hal-02990380

\author{
HAL Id: hal-02990380 \\ https://hal.science/hal-02990380
}

Submitted on 5 Nov 2020

HAL is a multi-disciplinary open access archive for the deposit and dissemination of scientific research documents, whether they are published or not. The documents may come from teaching and research institutions in France or abroad, or from public or private research centers.
L'archive ouverte pluridisciplinaire HAL, est destinée au dépôt et à la diffusion de documents scientifiques de niveau recherche, publiés ou non, émanant des établissements d'enseignement et de recherche français ou étrangers, des laboratoires publics ou privés. 


\title{
Nucleation of Brushite and Hydroxyapatite from Amorphous Calcium Phosphate Phases Revealed by Dynamic in situ Raman Spectroscopy
}

\author{
German Montes-Hernandez ${ }^{\mathrm{a} *}$ and François Renard ${ }^{\mathrm{a}, \mathrm{b}}$ \\ ${ }^{a}$ Univ. Grenoble Alpes, Univ. Savoie Mont Blanc, CNRS, IRD, IFSTTAR, ISTerre, 38000 \\ Grenoble, France \\ ${ }^{\mathrm{b}}$ The Njord Centre, Department of Geosciences, University of Oslo, box 1048 Blindern, 0316 \\ Oslo, Norway
}

*Corresponding author: Dr. German Montes-Hernandez

E-mail address: german.montes-hernandez@univ-grenoble-alpes.fr 


\section{Abstract}

Since the 1970s, it is admitted that calcium phosphate crystals nucleate from one or several early amorphous calcium phosphate phases into several in vivo and in vitro systems. However, the precise chemical composition, structure and transformation mechanism of these amorphous phases remain controversial. Here, we characterize the reaction mechanism and kinetics of formation of two phosphate crystals, brushite and hydroxyapatite, by using in situ Raman spectroscopy in batch reactors at $25^{\circ} \mathrm{C}$. We investigate three $\mathrm{pH}$ regimes to control the phosphate speciation in solution and used solutions with or without citric acid, a complexing agent that may stabilize the amorphous phases. As expected, brushite $\left(\mathrm{CaHPO}_{4} .2 \mathrm{H}_{2} \mathrm{O}\right)$ forms at $\mathrm{pH}<9.8$. Amorphous calcium phosphate (ACP: $\mathrm{CaHPO}_{4} \cdot \mathrm{nH}_{2} \mathrm{O}$ ) with short lifetime ( $<2$ minutes) and octocalcium phosphate (OCP: $\left.\mathrm{Ca} 8\left(\mathrm{HPO}_{4}\right)_{2}\left(\mathrm{PO}_{4}\right)_{4} .5 \mathrm{H}_{2} \mathrm{O}\right)$ are the main transient phases prior to brushite nucleation that occurs after $\sim 8$ minutes. At $\mathrm{pH}>11$, hydroxyapatite $\left(\mathrm{HAp}: \mathrm{Ca}_{10}\left(\mathrm{PO}_{4}\right)_{6}(\mathrm{OH})_{2}\right)$ nucleates after $>35$ minutes, depending on the experimental conditions. The reaction mechanism steps for hydroxyapatite are more complex compared to brushite. For hydroxyapatite formation, amorphous calcium phosphate phases with different chemical composition $\left(\mathrm{Ca}\left(\mathrm{HPO}_{4}\right)_{1-\mathrm{x}}\left(\mathrm{PO}_{4}\right)_{(2 / 3) x} \cdot \mathrm{nH}_{2} \mathrm{O}\right.$, with $\mathrm{x}$ in the range $0.2-$ 1, and with different lifetime may form. Amorphous tricalcium phosphate (ATCP: $\mathrm{Ca}\left(\mathrm{PO}_{4}\right)_{2 / 3} \cdot \mathrm{nH}_{2} \mathrm{O}$ or $\mathrm{Ca}_{3}\left(\mathrm{PO}_{4}\right)_{2} \cdot \mathrm{nH}_{2} \mathrm{O}$ when $\left.\mathrm{x}=1\right)$ is the most persistent phase which can transform either into OCP and then hydroxyapatite, or directly evolve into hydroxyapatite at $\mathrm{pH}>12.2$. The presence of citric acid retards the transformation kinetics by increasing the nucleation times of brushite and hydroxyapatite, but has little effect on the reaction mechanism steps. Finally, this study identifies new reactive pathways that characterize the formation of amorphous calcium phosphate phases and their transformation into brushite microcrystals or hydroxyapatite 
nanocrystals under abiotic conditions, relevant to a wide range of technological applications and natural environments. 


\section{TOC Graphic}
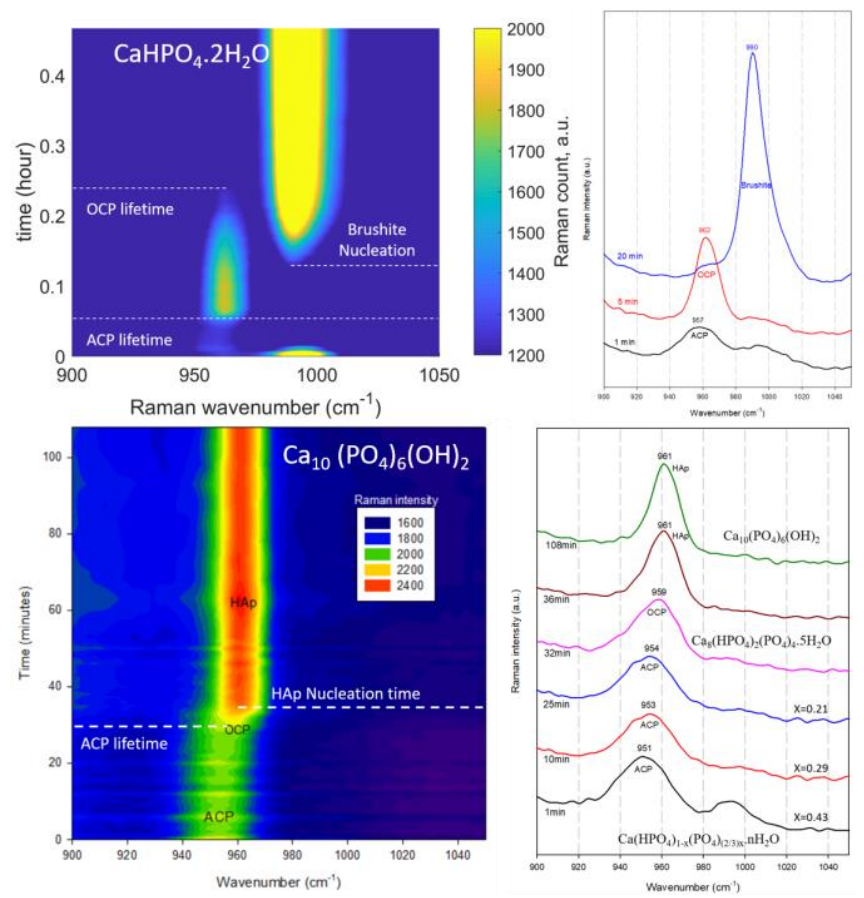

Synopsis: The nucleation of brushite and hydroxyapatite was monitored in real-time by Raman spectroscopy at $25{ }^{\circ} \mathrm{C}$. For both minerals, amorphous calcium phosphate $\left(\mathrm{Ca}\left(\mathrm{HPO}_{4}\right)_{1-}\right.$ $\left.{ }_{x}\left(\mathrm{PO}_{4}\right)_{(2 / 3) x} \cdot \mathrm{nH}_{2} \mathrm{O}\right)$ with different Raman signature instantaneously formed in the initial solution. Then, the amorphous phases transform into OCP, a crystalline transient phase. Finally, OCP transforms into brushite micro-crystals or into hydroxyapatite nanocrystals. 
Keywords: Time-resolved Raman spectroscopy; Nucleation and growth processes; Amorphous calcium phosphate; Brushite; Hydroxyapatite. 


\section{Introduction}

Calcium phosphates (e.g. hydroxyapatite, brushite, octo-calcium phosphate and amorphous calcium phosphates) are critically important biogenic minerals constituting hard tissues (bones, teeth and cartilages) in vertebrates. Phosphorus (P) and calcium (Ca) are also essential elements for the development of living organisms. Moreover, calcium phosphates find wide medical and industrial applications in dentistry, orthopedics, reconstructive surgery, food additives, fertilizers, and water depollution (1-6). The formation of calcium phosphates and the interactions and associations of these minerals with organic macromolecules have been widely investigated under in vivo and in vitro conditions in the last decades (7-10) in order to identify the nature of first primary precipitating particles, their lifetime and their chemical transformation into other minerals in aqueous media (11-20). For example, the formation of hydroxyapatite nanocrystals $\left(\mathrm{Ca}_{10}\left(\mathrm{PO}_{4}\right)_{6}(\mathrm{OH})_{2}\right)$ under biotic or abiotic conditions involves the early formation of a transient amorphous calcium phosphate phase (ACP) (11-26). This phase may either (1) transform directly by a solid-state transformation, (2) dissolve and reprecipitate to produce nanocrystalline hydroxyapatite, or (3) nucleate inside other amorphous phases (e.g. 9, 11, 16, 18, 24). The first theory of phosphate formation from precursor amorphous phases was proposed by Posner and Betts (11) who observed pre-nucleation clusters of $\mathrm{Ca}_{9}\left(\mathrm{PO}_{4}\right)_{6}$ with a size close to $\sim 1 \mathrm{~nm}$ (so-called 'Posner's cluster'). These authors proposed that the clusters not only could be the building blocks for ACP but also could play an important role during the transformation of $\mathrm{ACP}$ into hydroxyapatite, suggesting that ACP only dissociates into these clusters rather than undergoing a complete ionic dissolution $(11,16)$. However, the structure of pre-nucleation clusters during hydroxyapatite formation is still debated (e.g. 12-13, 25-26). For example, crystalline metastable 
phases such as octo-calcium phosphate (OCP) $\left(\mathrm{Ca}_{8}\left(\mathrm{HPO}_{4}\right)_{2}\left(\mathrm{PO}_{4}\right)_{4} .5 \mathrm{H}_{2} \mathrm{O}\right)$ and brushite $\left(\mathrm{CaHPO}_{4} .2 \mathrm{H}_{2} \mathrm{O}\right)$ have been proposed to form as transient phases prior to hydroxyapatite (HAp) nucleation. Therefore, a convincing temporal and/or spatial characterization of phosphate formation in natural or synthetic samples is still lacking (e.g. 5, 8, 15, 27-28) despite the use of sophisticated time-resolved measurements and simulations performed in the last two decades, such as in situ X-ray absorption (XAS), in situ small/wide-angle X-ray scattering (SAXS/WAXS), electron transmission microscopy (Cryo-TEM or liquid-cell TEM), atomic force microscopy (liquid-cell AFM) and ab initio numerical simulations based on the density functional theory (e.g. $1,12-13,19,25-27,29-30)$. Despite all these available techniques, more knowledge is required to understand how phosphate minerals nucleate and grow from solutions and slurries. In this context, time-resolved Raman spectroscopy measurements provide invaluable information on the nucleation, transformation and growth of particles and crystals, as recently demonstrated for several carbonates (31-33) and phosphates minerals (34-37). This spectroscopy technique allows discriminating between amorphous and crystalline phases that form early during the nucleation and growth of more stable minerals.

In the present study, the nucleation of brushite and hydroxyapatite was monitored in real-time and in situ by using Raman spectroscopy at $25{ }^{\circ} \mathrm{C}$. For both minerals, amorphous calcium phosphate $\left(\mathrm{Ca}\left(\mathrm{HPO}_{4}\right)_{1-\mathrm{x}}\left(\mathrm{PO}_{4}\right)_{(2 / 3) \mathrm{x}} \cdot \mathrm{nH} \mathrm{H}_{2} \mathrm{O}\right)$ with different Raman signature instantaneously formed as ionic solutions were rapidly mixed under mechanical stirring. Then, the amorphous phases transformed rapidly or slowly into OCP (crystalline transient phase). Finally, OCP transformed into brushite micro-crystals or into hydroxyapatite nanocrystals depending on the experimental investigated conditions. We varied the $\mathrm{pH}$, the $\mathrm{HPO}_{4}{ }^{2-} / \mathrm{PO}_{4}{ }^{3-}$ ratio and the $\mathrm{Ca} / \mathrm{P}$ ratio. The lifetime of amorphous 
and crystalline transient phases, reaction mechanisms and kinetics of formation of brushite and hydroxyapatite were then measured. We acquired several ex-situ measurements and images of the products recovered at the end of the experiments in order to characterize the average particles size, crystal shape and mineral composition.

\section{Materials and Methods}

\subsection{Time-lapse Raman spectroscopy}

The formation of brushite and hydroxyapatite was monitored using a Raman probe (785 nm infrared laser) immersed into a C22 Hastelloy batch reactor with internal volume of $600 \mathrm{ml}$. This experimental setup is described in a previous study (31). Raman spectra were collected with an exposure time of three or two seconds and averaged over three or two scans. The delay between successive acquisitions varied between fifteen seconds and one hour, depending on the investigated reaction. The duration of experiments was arbitrarily imposed from $2 \mathrm{~h}$ to $24 \mathrm{~h}$ and all collected spectra were saved on the control computer.

Selected Raman peaks (strongest peak) corresponding to identified mineral phases (see Table S1 and Table 1) were fitted by using simple or combined Gaussian models in order to calculate the peak Full Width at Half-Maximum (FWHM) and the integrated peak surface area as a function of time (Movie S1). The Raman signals were fitted using the following procedure. First, we selected a small region of the entire Raman spectrum that contained only the peaks relevant for the reaction studied. Then, the baseline was removed to correct for temporal fluctuations of the intensity of the signal. Finally, we decomposed the Raman signal into two, three, or four Gaussian curves, 
depending on the number of species present in the system. For each species, the position of the peak was fixed and the amplitude and standard deviation of each Gaussian was fitted using a nonlinear least squares method (Movies S1, S2, S3). This calculation provides the peak decomposition necessary to propose relevant reaction mechanisms and to quantify the kinetics of formation of calcium phosphates phases in aqueous solutions or slurries, including nucleation time and lifetime of minerals and aqueous species.

\subsection{Brushite ( $\left.\mathrm{CaHPO}_{4} .2 \mathrm{H}_{2} \mathrm{O}\right)$ from a phosphate solution}

$200 \mathrm{ml}$ of phosphate solution $\left(0.2 \mathrm{M}\right.$ of $\left.\mathrm{Na}_{2} \mathrm{HPO}_{4}, \mathrm{pH} 9.8\right)$ were firstly placed in the reactor under continuous stirring (400 rpm) at a temperature of $\sim 25^{\circ} \mathrm{C}$. Raman spectroscopy monitoring reveals a strong peak at $993 \mathrm{~cm}^{-1}$, characteristics of $\mathrm{HPO}_{4}{ }^{2-}$, before the addition of a calcium solution (Figure S1a). Then, $200 \mathrm{ml}$ of calcium solution ( $0.2 \mathrm{M}$ of $\mathrm{CaCl}_{2}, \mathrm{pH} 6.8$ ) were rapidly added into the system with a syringe for about one to two minutes leading to the instantaneous formation of a gel-like amorphous calcium phosphate phase with a Raman peak at $957 \mathrm{~cm}^{-1}$ (Figure S1b). The chemical transformation of this amorphous phase to crystalline phases was then monitored for $23 \mathrm{~h}$ with an acquisition frequency of one Raman spectrum every fifteen seconds during the first twenty minutes and every minute or five minutes in the remaining time. The same experiment was performed in presence of $1 \mathrm{~g}$ of citric acid $\left(\mathrm{C}_{6} \mathrm{H}_{8} \mathrm{O}_{7}\right)$, initially dissolved in the calcium solution in order to assess the effect of this acid on the kinetics and reaction mechanism. The citric acid is used here as a complexing agent that is expected to stabilize transient amorphous phosphate phases for longer durations than without acid. All chemical reactants with high purity $(>99 \%)$ were provided by Sigma-Aldrich.

9 


\subsection{Hydroxyapatite from $\mathrm{Na}_{2} \mathrm{HPO}_{4}-\mathrm{Ca}(\mathrm{OH})_{2}$ slurry}

$200 \mathrm{ml}$ of deionized water $\left(18.2\right.$ megaohm of resistivity) and $3 \mathrm{~g}$ of $\mathrm{Ca}(\mathrm{OH})_{2}(>96 \%$ of purity provided by Sigma-Aldrich) were placed in the reactor under continuous stirring (400 rpm) at a temperature of $\sim 25^{\circ} \mathrm{C}$. Direct Raman spectroscopy monitoring reveals a peak at $362 \mathrm{~cm}^{-1}$, characteristics of calcium hydroxide, before the addition of a phosphate solution (Figure S2). After the addition of $200 \mathrm{ml}$ of a phosphate solution $\left(0.2 \mathrm{M}\right.$ of $\left.\mathrm{Na}_{2} \mathrm{HPO}_{4}, \mathrm{pH} 9.8\right)$, the calcium hydroxide progressively dissolves (Figure S2) while hydroxyapatite forms under an alkaline $\mathrm{pH}$ higher than 12 , constrained by the release of $\mathrm{OH}^{-}$ions, as shown in the following overall reaction:

$10 \mathrm{Ca}(\mathrm{OH})_{2}+6 \mathrm{HPO}_{4}{ }^{2-} \Rightarrow \mathrm{Ca}_{10}\left(\mathrm{PO}_{4}\right)_{6}(\mathrm{OH})_{2}+12 \mathrm{OH}^{-}+6 \mathrm{H}_{2} \mathrm{O}$

This overall reaction involves the formation of amorphous and crystalline transient phases that were monitored in real-time by Raman spectroscopy for $18 \mathrm{~h}$ with an acquisition frequency of one Raman spectrum every fifteen seconds during the first twenty minutes, and every minute or five minutes in the remaining time. The same experiment was performed in presence of $1 \mathrm{~g}$ of citric acid $\left(\mathrm{C}_{6} \mathrm{H}_{8} \mathrm{O}_{7}\right)$, initially dissolved in the calcium hydroxide slurry

\subsection{Hydroxyapatite from ionic solutions}

$200 \mathrm{ml}$ of phosphate solution $\left(0.2 \mathrm{M}\right.$ of $\mathrm{PO}_{4}{ }^{3-} / \mathrm{HPO}_{4}{ }^{2-}, \mathrm{pH} \sim 12.4$ adjusted with $\left.\mathrm{NaOH}\right)$ were firstly placed in the reactor under continuous stirring ( $400 \mathrm{rpm}$ ) at a temperature of $\sim 25^{\circ} \mathrm{C}$. Direct Raman spectroscopy monitoring confirms the presence of peaks for $\mathrm{HPO}_{4}{ }^{2-}$ at $992 \mathrm{~cm}^{-1}$ and $\mathrm{PO}_{4}{ }^{3-}$ at 939

$\mathrm{cm}^{-1}$, before the addition of a calcium solution (Figure S3a). Then, $200 \mathrm{ml}$ of calcium solution 
$\left(0.33 \mathrm{M}\right.$ of $\left.\mathrm{CaCl}_{2}\right)$ were rapidly added into the system with a syringe for about $1-2$ minutes. Similar to the brushite experiment, the fast mixing of these two ionic solutions led to the instantaneous formation of a gel-like phase that contained an amorphous calcium phase with a Raman peak at $951 \mathrm{~cm}^{-1}$ (Figure S3b). The lifetime and chemical transformation of this gel into crystalline phases were monitored in real-time for $23 \mathrm{~h}$ with an acquisition frequency of one Raman spectrum every fifteen seconds during the first twenty minutes and every minute or five minutes in the remaining time. The overall reaction to form hydroxyapatite can be written as follows:

$2 \mathrm{HPO}_{4}{ }^{2-}+4 \mathrm{PO}_{4}{ }^{3-}+2 \mathrm{OH}^{-}+10 \mathrm{Ca}^{2+} \Rightarrow \mathrm{Ca}_{10}\left(\mathrm{PO}_{4}\right)_{6}(\mathrm{OH})_{2}+2 \mathrm{H}^{+}$

In contrast to the formation of hydroxyapatite from a calcium hydroxide slurry (reaction 1), the synthesis of hydroxyapatite using ionic solutions releases protons, which produces a decrease of $\mathrm{pH}$ during the experiment from $\sim 12.4$ to $\sim 11$.

In summary, three different $\mathrm{pH}$ regimes were investigated in this study using equimolar $\mathrm{Ca} / \mathrm{P}$ ratio or hydroxyapatite stochiometric ratio $(\mathrm{Ca} / \mathrm{P}=1.66)$ and two different $\mathrm{Ca}$ sources $\left(\mathrm{CaCl}_{2}\right.$ and $\left.\mathrm{Ca}(\mathrm{OH})_{2}\right)$. The $\mathrm{pH}$ in the solutions and slurries was systematically measured at the beginning and the end of each experiment. We used a conventional $\mathrm{pH}$ meter (Mettler Toledo MA235). However, the in-situ $\mathrm{pH}$ variations during precipitation experiments were not recorded. Table 1 summarizes all experiments performed in the present study. Each experiment was repeated at least three times to verify the reproducibility of the results. 


\subsection{Ex situ characterization of precipitates}

At the end of each experiment, the solid product was recovered by centrifugation and washed twice with ultrapure water and once with ethanol. Then, it was dried at $60^{\circ} \mathrm{C}$ for $48 \mathrm{~h}$. The dry solid products were stored in plastic flasks for subsequent characterization of selected samples by field emission gun scanning electron microscopy (FESEM) and powder X-ray diffraction (XRD).

For high resolution imaging, the solid products were dispersed by ultrasonic treatment in absolute ethanol for five to ten minutes. One or two droplets of the suspension were then deposited directly on an aluminum support and coated with gold and platinum. The morphology of the crystals was imaged using a Zeiss Ultra 55 field emission gun scanning electron microscope (FESEM) with a maximum spatial resolution of approximately $1 \mathrm{~nm}$ at $15 \mathrm{kV}$.

XRD analyses were performed using a Siemens D5000 diffractometer in Bragg-Brentano geometry, equipped with a theta-theta goniometer with a rotating sample holder. The XRD patterns

were collected using $\mathrm{Cu} \mathrm{k} \alpha_{1}\left(\lambda_{\mathrm{k} \alpha 1}=1.5406 \AA \hat{)}\right)$ and $\mathrm{k} \alpha_{2}\left(\lambda_{\mathrm{k \alpha} 2}=1.5444 \AA \hat{)}\right)$ radiations in the range $2 \theta=$ $10-70^{\circ}$ with a step size of $0.04^{\circ}$ and a counting time of six seconds per step.

\section{Results and discussion}

\subsection{Brushite formation: Reaction mechanism and kinetics}

The quick mixing of two equimolar ionic solutions, one containing $\mathrm{HPO}_{4}{ }^{2-}(0.2 \mathrm{M}, \mathrm{pH} \sim 9.8)$ and the other containing $\mathrm{Ca}^{2+}(0.2 \mathrm{M}, \mathrm{pH} \sim 6.8)$, leads the instantaneous formation of an amorphous calcium phosphate (ACP: $\mathrm{CaHPO}_{4} \cdot \mathrm{nH}_{2} \mathrm{O}$ ) with a peak at $957 \mathrm{~cm}^{-1}$ (Figure $\mathrm{S} 1 \mathrm{~b}$ ). This Raman signature is 12 
transient with a lifetime of about two minutes. Then, ACP transforms into octo-calcium phosphate (OCP: $\left.\mathrm{Ca}_{8}\left(\mathrm{HPO}_{4}\right)_{2}\left(\mathrm{PO}_{4}\right)_{4} .5 \mathrm{H}_{2} \mathrm{O}\right)$ with a peak at $962 \mathrm{~cm}^{-1}$. This crystalline phase nucleates from ACP after two minutes and its maximum Raman intensity is reached after five minutes. The OCP is also a transient phase that progressively transforms into brushite $\left(\mathrm{CaHPO}_{4} \cdot 2 \mathrm{H}_{2} \mathrm{O}\right)$, with a peak at $990 \mathrm{~cm}^{-1}$, after a nucleation time of 7.5 minutes. Brushite reaches a maximum Raman intensity after 24 minutes. The progressive increase of the brushite Raman peak is proportional the decrease of OCP Raman intensity until the total consumption of OCP. This sequence of reactions and kinetics are summarized in Figure 1, Figure S4 and Movie S1. Based on these data, the following reaction mechanism is proposed:

1. Instantaneous formation of ACP:

$\mathrm{HPO}_{4}{ }^{2-}+\mathrm{Ca}^{2+}+\mathrm{nH}_{2} \mathrm{O} \Rightarrow \mathrm{CaHPO}_{4} \cdot \mathrm{nH}_{2} \mathrm{O}$

Amorphous calcium phosphate containing only $\mathrm{HPO}_{4}{ }^{2-}(\mathrm{Ca} / \mathrm{P}=1)$ is assumed at this investigated $\mathrm{pH}$ regime where only $\mathrm{HPO}_{4}{ }^{2-}$ ions may exist in solution. However, the incorporation of phosphate into the amorphous phase $\left(\mathrm{Ca}\left(\mathrm{HPO}_{4}\right)_{1-\mathrm{x}}\left(\mathrm{PO}_{4}\right)_{(2 / 3) \mathrm{x}} \cdot \mathrm{nH}_{2} \mathrm{O}\right)$ and the removal of protons $\left(\mathrm{H}^{+}\right)$at the solid-fluid interface are not excluded.

2. Transformation of ACP into OCP via a solid-state crystallization pathway:

$8 \mathrm{CaHPO}_{4} \cdot \mathrm{nH}_{2} \mathrm{O}+5 \mathrm{H}_{2} \mathrm{O} \Rightarrow \mathrm{Ca} 8\left(\mathrm{HPO}_{4}\right)_{2}\left(\mathrm{PO}_{4}\right)_{4} .5 \mathrm{H}_{2} \mathrm{O}+2 \mathrm{H}_{2} \mathrm{PO}_{4}^{-}+2 \mathrm{H}^{+}+8 \mathrm{nH}_{2} \mathrm{O}$

This reaction implies the protonation of residual phosphate ions as confirmed by the peaks at 880 and $1080 \mathrm{~cm}^{-1}$ assigned to $\mathrm{H}_{2} \mathrm{PO}_{4}{ }^{-}$(Figure S5 and Table S1). This means that a significant decrease of $\mathrm{pH}$ (probably, $\mathrm{pH}<6.7$ ) takes place in first minutes that favor then the OCP transformation into 
brushite as directly monitored by Raman spectroscopy (Figure 1) and described below by reaction 5.

In addition, a solid-state crystallization is assumed because the overall transformation of ACP into OCP takes place abruptly in less than fifteen seconds, which corresponds to the time resolution in our experiments, as illustrated in Figure 1.

3. Transformation of OCP into brushite via a dissolution-recrystallization pathway:

$\mathrm{Ca} 8\left(\mathrm{HPO}_{4}\right)_{2}\left(\mathrm{PO}_{4}\right)_{4} .5 \mathrm{H}_{2} \mathrm{O}+2 \mathrm{H}_{2} \mathrm{PO}_{4}{ }^{-}+2 \mathrm{H}^{+}+11 \mathrm{H}_{2} \mathrm{O} \Rightarrow 8 \mathrm{CaHPO}_{4} .2 \mathrm{H}_{2} \mathrm{O}$

Dissolution-recrystallization pathway is here assumed because the OCP transient phase is progressively consumed by the formation and growth of brushite (Figure 1). This interpretation is supported by a temporal increase the FWHM of the main OCP Raman peak until its total consumption (Figure S6). This result can be interpreted by an average decrease of the crystals size, $\mathrm{z}$, of OCP with z $\alpha$ 1/FWHM ${ }_{\mathrm{OCP}}$, due to a progressive dissolution process. Conversely, the temporal decrease of FWHM for brushite formation indicates a crystal growth process.

Ex-situ characterization of solids recovered at the end of experiments by FESEM and XRD confirmed the presence of elongated microcrystals $(>20 \mu \mathrm{m})$ of brushite (see Figure S7).

In the presence of citric acid, the reaction mechanism remains very similar because the reactions 3 to 5 occur and the only measurable difference is a very slight transformation of brushite into hydroxyapatite confirmed by XRD in the recovered solid product (experiment 2 in Table 1 and Figure S8). In presence of citric acid, the transformation kinetics, and mainly the transformation of OCP into brushite (reaction 5), are significantly retarded from 15 (Figure 1) to 400 minutes (Figure 2). Conversely, the formation of ACP (reactions 3) and the transformation of ACP into OCP 
(reaction 4) are only slightly retarded, as displayed in Figure 2.

\subsection{Hydroxyapatite formation from $\mathrm{Ca}(\mathrm{OH})_{2}$ slurry: Reaction mechanism and kinetics}

In this case, a phosphate ionic solution $\left(0.2 \mathrm{M}\right.$ of $\left.\mathrm{HPO}_{4}{ }^{2-}, \mathrm{pH} \sim 9.8\right)$ was rapidly added to a $\mathrm{Ca}(\mathrm{OH})_{2}$ slurry $\left(0.015 \mathrm{~g} / \mathrm{g}_{\mathrm{H} 2 \mathrm{O}}, \mathrm{pH} 12.2\right)$. As expected, an amorphous calcium phosphate (ACP1) with a peak at $954 \mathrm{~cm}^{-1}$ forms instantaneously in the first fifteen seconds, and has a lifetime of less than one minute. The ACP1 rapidly transforms into another amorphous calcium phase with a peak at 943 $\mathrm{cm}^{-1}$ (ACP2), a transformation accompanied by a transient release of $\mathrm{HPO}_{4}{ }^{2-}$ ions with a peak at $993 \mathrm{~cm}^{-1}$ (Figure 3). Based on this result, we assume that the shift of the peak position of the calcium amorphous phases is exclusively related to the $\mathrm{HPO}_{4}{ }^{2-}$ or $\mathrm{PO}_{4}{ }^{3-}$ structural content into the amorphous phase $\left(\mathrm{Ca}\left(\mathrm{HPO}_{4}\right)_{1-\mathrm{x}}\left(\mathrm{PO}_{4}\right)_{(2 / 3) x} \cdot \mathrm{nH}_{2} \mathrm{O}\right.$; with $\mathrm{x}$ that varies between 0 and 1$)$. Therefore, the calcium amorphous phase can show a Raman signature with broad peaks between $943 \mathrm{~cm}^{-1}$ for $\mathrm{Ca}_{3}\left(\mathrm{PO}_{4}\right)_{2} \cdot \mathrm{nH}_{2} \mathrm{O}(\mathrm{ATCP})$, and $957 \mathrm{~cm}^{-1}$ for $\mathrm{CaHPO}_{4} \cdot \mathrm{nH}_{2} \mathrm{O}(\mathrm{ACP})$. This result is illustrated in Figure S9, where the parameter $x$ can be calculated by a linear interpolation of the peak position in the interval $943-957 \mathrm{~cm}^{-1}\left(\mathrm{x}=68.357-(1 / 14) * \mathrm{P}_{\mathrm{ACP}}\right.$ : where $\mathrm{P}_{\mathrm{ACP}}$ is the position in $\mathrm{cm}^{-1}$ comprised between 943 and 957). Then, the ATCP slowly transforms into hydroxyapatite with a peak at 963 $\mathrm{cm}^{-1}$. The OCP clearly detected in the brushite systems as a transient phase (experiments 1 and 2 ) is also expected to form in more alkaline systems. However, the strongest Raman peak of OCP $\left(962 \mathrm{~cm}^{-1}\right)$ is very close to the main peak of hydroxyapatite $\left(963 \mathrm{~cm}^{-1}\right)$. For this reason, the OCPlike layers transient phase is also considered in the deconvolution peak fitting, as illustrated in the Movie S2, and in the kinetics behavior summarized in Figure S10. Note that the OCP-like layers formation in this particular case remains speculative because we did not detect this phase in the solid product after the experiment. However, we needed this phase to fit the Raman data. Based on 15 
these time-resolved Raman spectroscopy measurements, the following reaction mechanism is suggested:

1. Instantaneous formation of ACP1:

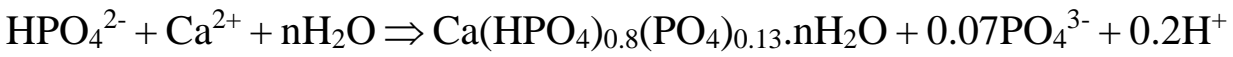

Here, we assume that the produced protons $\left(\mathrm{H}^{+}\right)$are instantaneously neutralized by the calcium hydroxide dissolution $\left(\mathrm{Ca}(\mathrm{OH})_{2} \Rightarrow \mathrm{Ca}^{2+}+2 \mathrm{OH}^{-}\right)$such that a high alkaline $\mathrm{pH}(>12.2)$ is maintained during the experiment as expected by overall reaction 1 (see the section Materials and Methods).

2. Transformation of ACP1 into ATCP via a solid-state transformation pathway:

$\mathrm{Ca}\left(\mathrm{HPO}_{4}\right)_{0.8}\left(\mathrm{PO}_{4}\right)_{0.13} \cdot \mathrm{nH}_{2} \mathrm{O} \Rightarrow \mathrm{Ca}\left(\mathrm{PO}_{4}\right)_{2 / 3} \cdot \mathrm{nH}_{2} \mathrm{O}+0.27 \mathrm{HPO}_{4}{ }^{2-}+0.53 \mathrm{H}^{+}$

Solid-state transformation is assumed because ACP1 has a short lifetime, less than one minute, and its transformation into ATCP takes place abruptly, as shown in Figure 3 . The phase $\mathrm{Ca}\left(\mathrm{PO}_{4}\right)_{2 / 3} \cdot \mathrm{nH}_{2} \mathrm{O}$ is equivalent to $\mathrm{Ca}_{3}\left(\mathrm{PO}_{4}\right)_{2} \cdot \mathrm{nH}_{2} \mathrm{O}$ reported in the literature and is constituted mainly by the so-called Posner's clusters $\mathrm{Ca}_{9}\left(\mathrm{PO}_{4}\right)_{6}$ with $\sim 1 \mathrm{~nm}$ size (11). The reaction 7 implies a release of $\mathrm{HPO}_{4}{ }^{2-}$ ions and protons $\left(\mathrm{H}^{+}\right)$that are also detected by Raman spectroscopy (Figure 3). These ions rapidly react to form OCP as illustrated in the following reaction, and residual phosphate ions are transformed to $\mathrm{PO}_{4}{ }^{3-}$, the main phosphate aqueous species in high alkaline aqueous media. Residual protons $\left(\mathrm{H}^{+}\right)$are neutralized to water $\left(\mathrm{H}^{+}+\mathrm{OH}^{-} \Rightarrow \mathrm{H}_{2} \mathrm{O}\right)$.

3. Transformation of ATCP to OCP-like layers:

$8 \mathrm{Ca}\left(\mathrm{PO}_{4}\right)_{2 / 3} \cdot \mathrm{nH}_{2} \mathrm{O}+0.67 \mathrm{HPO}_{4}{ }^{2-}+1.33 \mathrm{H}^{+}+5 \mathrm{H}_{2} \mathrm{O} \Rightarrow \mathrm{Ca} 8\left(\mathrm{HPO}_{4}\right)_{2}\left(\mathrm{PO}_{4}\right)_{4} .5 \mathrm{H}_{2} \mathrm{O}+8 \mathrm{nH}_{2} \mathrm{O}$

As indicated above, only OCP-like layers were suspected in the raw Raman data, but, it is necessary to improve the deconvolution fitting, particularly in the first 90 minutes (see Figure S10 and Movie 
S2). Moreover, the ATCP phase has a long lifetime and coexists with hydroxyapatite until the end of the experiment. For this reason, two different mechanisms may occur simultaneously to form hydroxyapatite in high alkaline media.

4a. Transformation of OCP-like layers into hydroxyapatite:

$\mathrm{Ca}_{8}\left(\mathrm{HPO}_{4}\right)_{2}\left(\mathrm{PO}_{4}\right)_{4} .5 \mathrm{H}_{2} \mathrm{O}+2 \mathrm{Ca}^{2+}+2 \mathrm{OH}^{-} \Rightarrow \mathrm{Ca}_{10}\left(\mathrm{PO}_{4}\right)_{6}(\mathrm{OH})_{2}+2 \mathrm{H}^{+}+5 \mathrm{H}_{2} \mathrm{O}$

4b. Transformation of ATCP into hydroxyapatite:

$10 \mathrm{Ca}\left(\mathrm{PO}_{4}\right)_{2 / 3} \cdot \mathrm{nH}_{2} \mathrm{O}+2 \mathrm{OH}^{-} \Rightarrow \mathrm{Ca}_{10}\left(\mathrm{PO}_{4}\right)_{6}(\mathrm{OH})_{2}+0.66 \mathrm{PO}_{4}{ }^{3-}+10 \mathrm{nH}_{2} \mathrm{O}$

Both reactions (9 and 10) participate to the formation of hydroxyapatite, as shown by the temporal behavior of the Raman intensity of selected peaks (Figure 4) and the integrated peak surface areas of concerned phases (Figure S10 and Movie S2). However, the low temporal variation of the FWHM parameter (Figure S11) does not allow to conclude if the reactions takes place via a dissolution-recrystallization pathway, as clearly deduced for brushite system. In this case, partial dissolution, i.e. conserving $\mathrm{Ca} 9\left(\mathrm{PO}_{4}\right)_{6}$ clusters of $\sim 1 \mathrm{~nm}$ size as building primary units, combined with self-assembly aggregation could operate to form hydroxyapatite, as suggested in previous studies $(11-12,14,16,18)$. Unfortunately, Raman dynamic in situ monitoring cannot provide clear or complementary information on this specific important interfacial process.

Ex-situ characterization of solids recovered after the experiments by FESEM and XRD confirm the presence of acicular nanocrystals of hydroxyapatite, with size $<100 \mathrm{~nm}$, and, probably, some residual amorphous calcium phosphate, as attested by the presence of very fine particles with size $<20 \mathrm{~nm}$ (Figure S12).

Concerning the effect of citric acid, Raman data reveal that the reaction mechanism remains very similar because the reactions 6 to 10 can be confirmed. The main difference concerns reaction 6 
where the transient amorphous calcium carbonate (ACP1) has a Raman signature at $957 \mathrm{~cm}^{-1}$, and therefore contains only $\mathrm{HPO}_{4}{ }^{2-}$ in its structure $\left(\mathrm{CaHPO}_{4} \cdot \mathrm{nH}_{2} \mathrm{O}\right)$, as illustrated in Figure S9. The other difference is that the transformation kinetics of transient phases into hydroxyapatite, including the nucleation time (reactions 8-10) is significantly retarded, as illustrated in Figure 5. Conversely, the formation of ACP1 (reaction 6) and the transformation of ACP1 to ATCP (reaction 7) are slightly retarded only.

\subsection{Hydroxyapatite formation from mixture of ionic solutions: Reaction mechanism and kinetics}

The quick mixing of two ionic solutions with hydroxyapatite stochiometric ratio, $\mathrm{Ca} / \mathrm{P}=1.66$, one containing $0.2 \mathrm{M}$ of $\mathrm{PO}_{4}{ }^{3-} / \mathrm{HPO}_{4}{ }^{2-}(\mathrm{pH} 12.4$ adjusted with $\mathrm{NaOH})$ and the other containing $\mathrm{Ca}^{2+}(0.33 \mathrm{M}, \mathrm{pH} 6.8)$, leads to the instantaneous formation of amorphous calcium phosphate $\left(\mathrm{ACP}: \mathrm{Ca}\left(\mathrm{HPO}_{4}\right)_{1-\mathrm{x}}\left(\mathrm{PO}_{4}\right)_{(2 / 3) \mathrm{x}} \cdot \mathrm{nH}_{2} \mathrm{O} ; \mathrm{x}=0.43\right.$ ) with a peak at $951 \mathrm{~cm}^{-1}$ (Figure 6). This Raman signature is transient with a short lifetime of three to four minutes. The total lifetime of ACP is about 30 minutes, and the position of its Raman peak varies from $951 \mathrm{~cm}^{-1}(\mathrm{x}=0.43)$ to $954 \mathrm{~cm}^{-1}$ $(\mathrm{x}=0.21)$ prior to its transformation into OCP. Then, OCP is transformed into hydroxyapatite with a nucleation time of 36 minutes (Figure 6). This result is supported by the deconvolution fitting of selected Raman peaks (Figure S13 and Movie S3). The formation of OCP-like layers in this case remains speculative, but in agreement with literature $(5,27,28)$. Based on these time-resolved Raman spectroscopy measurements, the following reaction mechanism steps are proposed:

1. Instantaneous formation of ACP:

$(1-x) \mathrm{HPO}_{4}{ }^{2-}+(2 / 3) \mathrm{xPO}_{4}{ }^{3-}+\mathrm{Ca}^{2+}+\mathrm{nH}_{2} \mathrm{O} \Rightarrow \mathrm{Ca}\left(\mathrm{HPO}_{4}\right)_{1-\mathrm{x}}\left(\mathrm{PO}_{4}\right)_{(2 / 3) x} \cdot \mathrm{nH}_{2} \mathrm{O}$

Here, $\mathrm{x}$ varies between 0.43 and 0.21 , i.e. the ACP is structurally enriched with $\mathrm{HPO}_{4}{ }^{2-}$ as a function of time prior to its transformation into OCP-like layers. Clusters aggregation process combined 18 
with partial dissolution could be the responsible to this variation of phosphate content into ACP.

2. Transformation of ACP into OCP-like layers:

$8 \mathrm{Ca}\left(\mathrm{HPO}_{4}\right)_{0.8}\left(\mathrm{PO}_{4}\right)_{0.13} \cdot \mathrm{nH}_{2} \mathrm{O}+2.96 \mathrm{PO}_{4}{ }^{3-}+5 \mathrm{H}_{2} \mathrm{O} \Rightarrow \mathrm{Ca}_{8}\left(\mathrm{HPO}_{4}\right)_{2}\left(\mathrm{PO}_{4}\right)_{4} \cdot 5 \mathrm{H}_{2} \mathrm{O}+4.4 \mathrm{HPO}_{4}{ }^{2-}+8 \mathrm{nH}_{2} \mathrm{O}$

A solid-state transformation is proposed because the transformation of ACP into OCP-like layers takes place over a short duration, in less than two minutes, and the position of the Raman peak shifts rapidly from $954 \mathrm{~cm}^{-1}$ to $959 \mathrm{~cm}^{-1}$ (Figure 6).

3. Transformation of OCP-like layers into hydroxyapatite:

$\mathrm{Ca}_{8}\left(\mathrm{HPO}_{4}\right)_{2}\left(\mathrm{PO}_{4}\right)_{4} .5 \mathrm{H}_{2} \mathrm{O}+2 \mathrm{Ca}^{2+}+2 \mathrm{OH}^{-} \Rightarrow \mathrm{Ca}_{10}\left(\mathrm{PO}_{4}\right)_{6}(\mathrm{OH})_{2}+2 \mathrm{H}^{+}+5 \mathrm{H}_{2} \mathrm{O}$

As explained above, the partial dissolution of OCP-like layers and ACP conserves $\mathrm{Ca}_{9}\left(\mathrm{PO}_{4}\right)_{6}$ clusters of $\sim 1 \mathrm{~nm}$ size as primary building unit $(11,16)$. These clusters can aggregate to form hydroxyapatite as described in the literature $(11-12,14,16,18)$. This interpretation is supported by the slight progressive shift of the position of the Raman peak from 960 to $962 \mathrm{~cm}^{-1}$ and the slight decrease of FWHM of hydroxyapatite (Figure S14).

\section{Concluding remarks}

Time-resolved Raman measurements reveal that amorphous calcium phosphate $\left(\mathrm{Ca}\left(\mathrm{HPO}_{4}\right)_{1-}\right.$ $\left.{ }_{x}\left(\mathrm{PO}_{4}\right)_{(2 / 3) x} \cdot \mathrm{nH}_{2} \mathrm{O}\right)$ has specific Raman signature comprised between $943 \mathrm{~cm}^{-1}$ for ATCP $\left(\mathrm{Ca}_{3}\left(\mathrm{PO}_{4}\right)_{2} \cdot \mathrm{nH}_{2} \mathrm{O}, \mathrm{x}=1\right)$ and $957 \mathrm{~cm}^{-1}$ for $\mathrm{ACP}\left(\mathrm{CaHPO}_{4} \cdot \mathrm{nH}_{2} \mathrm{O}, \mathrm{x}=0\right)$, as shown in the Figures 1,3 , 6 and S9. This specific Raman signature does not overlap with the strongest Raman peaks of crystalline calcium phosphates phases formed at ambient temperature (OCP at $960-962 \mathrm{~cm}^{-1}$, brushite at $990 \mathrm{~cm}^{-1}$ and hydroxyapatite at $\left.962-963 \mathrm{~cm}^{-1}\right)$ and aqueous species $\left(\mathrm{H}_{2} \mathrm{PO}_{4}^{-}\right.$at $880 \mathrm{~cm}^{-}$

1 and $1080 \mathrm{~cm}^{-1}, \mathrm{HPO}_{4}{ }^{2-}$ at $992-993 \mathrm{~cm}^{-1}$, and $\mathrm{PO}_{4}{ }^{3-}$ at $\left.939 \mathrm{~cm}^{-1}\right)$. Based on these spectral Raman 19 
signatures monitored in real-time and under in situ conditions, we demonstrate that the ACP that contains only $\mathrm{HPO}_{4}{ }^{2-}$ in its structure $\left(\mathrm{CaHPO}_{4} \cdot \mathrm{nH}_{2} \mathrm{O}, \mathrm{x}=0\right)$ has a short lifetime $(<5 \mathrm{~min})$ in solution (experiments 1-2 in Table 1, Figures 1-2). Conversely, the ATCP that contains only $\mathrm{PO}_{4}{ }^{3-}$ in its structure $\left(\mathrm{Ca}\left(\mathrm{PO}_{4}\right)_{(2 / 3)} \cdot \mathrm{nH}_{2} \mathrm{O}\right.$ or $\left.\mathrm{Ca}_{3}\left(\mathrm{PO}_{4}\right)_{2} \cdot \mathrm{nH}_{2} \mathrm{O}, \mathrm{x}=1\right)$ has a much longer lifetime $(>24 \mathrm{~h})$ in solution (experiments 3-4 in Table 1, Figure 5). These results are supported by experiment 5 (Table 1), where the ACP contains initially both $\mathrm{PO}_{4}{ }^{3-}$ and $\mathrm{HPO}_{4}{ }^{2-}$ in its structure with $\mathrm{x}=0.4$. This phosphate composition in ACP varies with time until $\mathrm{x}=0.2$ prior to its crystallization into a more stable phase. In this case, an intermediate lifetime of $\sim 35$ minutes is measured (Figure 6). In addition to these fundamental insights, the reaction mechanism steps and kinetics during crystallization of brushite and hydroxyapatite can be determined under specific experimental conditions. For example, brushite $\left(\mathrm{CaHPO}_{4} .2 \mathrm{H}_{2} \mathrm{O}\right)$ forms when the $\mathrm{pH}$ is $<9.8$; amorphous calcium phosphate (ACP: $\left.\mathrm{CaHPO}_{4} \cdot \mathrm{nH}_{2} \mathrm{O}\right)$ with short lifetime $(<2$ minutes) and octocalcium phosphate (OCP: $\left.\mathrm{Ca}_{8}\left(\mathrm{HPO}_{4}\right)_{2}\left(\mathrm{PO}_{4}\right)_{4} .5 \mathrm{H}_{2} \mathrm{O}\right)$ are the main transient phases prior to the nucleation of brushite that occurs after $\sim 8$ minutes (see reactions $3-5$ ). When $\mathrm{pH}$ is $>11$, the hydroxyapatite $\left(\mathrm{Ca}_{10}\left(\mathrm{PO}_{4}\right)_{6}(\mathrm{OH})_{2}\right)$ nucleates rapidly, after about 35 minutes, depending on the experimental conditions. Herein, amorphous calcium phosphate with different chemical compositions (ATCP: $\mathrm{Ca}\left(\mathrm{HPO}_{4}\right)_{1-\mathrm{x}}\left(\mathrm{PO}_{4}\right)_{(2 / 3) \mathrm{x}} \cdot \mathrm{nH}_{2} \mathrm{O}$; $\mathrm{x}$ from 0.2 to 1$)$ and with different lifetimes can form and then transform into OCP-like layers. Then, the OCP transient phase transforms into hydroxyapatite. The ATCP phase can also transform directly into hydroxyapatite when $\mathrm{pH}$ is $>12.2$, without forming OCP as an intermediate phase (see reactions 6-10 and/or 11-13). In conclusion, the present study reports fundamental insights on the formation of amorphous calcium phosphate phases and their transformation into brushite micro-crystals or hydroxyapatite nanocrystals under abiotic conditions, relevant to technological applications and/or natural settings. 
The early formation of amorphous phases and their transformation into transient or stables crystalline phases is now considered to be a generalized reaction pathway during the formation of calcium carbonate and phosphate minerals and/or biominerals in aqueous systems. This crystallization pathway agrees with Ostwald's rule, but transient phases are not necessary polymorphs; in fact, they can have different chemical compositions and different particle sizes. Moreover, thermodynamic and kinetic arguments should be considered in the crystallization tendency (e.g. 38, this study). In this way, multi-steps nucleation events may exist and combine various reaction mechanisms at the solid-fluid interfaces. Thus, solid-state transition, dissolutionrecrystallization, self-assembly aggregation and partial dissolution-aggregation may operate together during nucleation and growth processes (e.g. 31-33 and the present study). In this case, the classical nucleation theory (CNT), the most common theoretical formalism to quantify nucleation and growth rates (including variation of particles size distribution) cannot successfully be applied in its original formalism as proposed in the last three decades by various research groups (e.g. 39-42). These groups have proposed an alternative descriptive approach called non-classical nucleation and crystallization pathways (including pre-nucleation clusters). However, in the absence of a theoretical quantitative formalism to describe the so-called nonclassical nucleation, the improved and/or adapted classical nucleation theory remains the best tool to simulate nonclassical nucleation of crystals and/or particles (e.g. 12, 43-45). 


\section{Supporting Information Available}

Table S1 and Figures S1-S14 as described in the text (PDF). Time evolution of the peaks of the main mineral phases during experiments 1,3 and 5 (AVI) 


\section{Acknowledgements}

The authors acknowledge funding from the French National Centre for Scientific Research (CNRS), the Université Grenoble Alpes (UGA) and the Labex OSUG@2020 (Investissement

d'avenir-ANR10-LABX56). The FUNMIN project funded an additional Raman probe for ex-situ measurements in suspensions and powders. We thank Nathaniel Findling for technical assistance. 


\section{References}

(1) Wang, X.; Jie Yang, J.; Andrei, C. M.; Soleymani, L.; Grandfield, K. Biomineralization of calcium phosphate revealed by in situ liquid-phase electron microscopy. Comm. Chem. 2018, 1:80

(2) Niu, X.; Liu, Z.; Tian, F.; Chen, S.; Lei, L.; Jiang, T.; Feng, Q.; Fan, Y. Sustained delivery of calcium and orthophosphate ions from amorphous calcium phosphate and poly(L-lactic acid)based electrospinning nanofibrous scaffold. Sci. Rep. 2017, 7:45655

(3) de Aza, P. N. ; Santos, C. ; Pazo, A. ; de Aza, S. ; Cusco, R. ; Artús L. Vibrational Properties of Calcium Phosphate Compounds. 1. Raman Spectrum of $\beta$-Tricalcium Phosphate. Chem. Mater. 1997, 9, 912-915.

(4) Combes, C.; Rey, C. Amorphous calcium phosphates: Synthesis, properties and uses in biomaterials. Acta Biomater. 2010, 6, 3362-3378.

(5) Eliaz, N.; Metoki, N. Calcium Phosphate Bioceramics: A Review of Their History, Structure, Properties, Coating Technologies and Biomedical Applications. Materials 2017, 10, 334.

(6) Bohner, B.; Bánsági Jr., T.; Tóth, A.; Horváth, D.; Taylor, A. F. Periodic Nucleation of Calcium Phosphate in a Stirred Biocatalytic Reaction. Angew. Chem. Int. Ed. 2020, 59, 2823-2828.

(7) Cross, K. J.; Huq, N. L.; Reynolds, E. C. Casein Phosphopeptide-Amorphous Calcium Phosphate Nanocomplexes: A Structural Model. Biochem. 2016, 55, 4316-4325. 
(8) Lotsari, A.; Rajasekharan, A. K.; Halvarsson, M.; Andersson, M. Transformation of amorphous calcium phosphate to bone-like apatite. Nature Comm. 2018, 9:4170

(9) Tsujia, T.; Onuma, K.; Yamamoto, A.; Iijima, M.; Shiba, K. Direct transformation from amorphous to crystalline calcium phosphate facilitated by motif-programmed artificial proteins. PNAS 2008, 105, 16866-16870.

(10) Zhang, Y. Y.; Wong, H. M.; McGrath, C. P. J.; Li, Q. L. In vitro and in vivo evaluation of electrophoresis-aided casein phosphopeptide-amorphous calcium phosphate remineralization system on pH-cycling and acid-etching demineralised enamel. Sci. Rep. 2018 8:8904

(11) Posner, A. S.; Betts, F. Synthetic Amorphous Calcium Phosphate and Its Relation to Bone Mineral Structure. Acc. Chem. Res. 1975, 8, 273-281.

(12) Habraken et al. Ion-association complexes unite classical and non-classical theories for the biomimetic nucleation of calcium phosphate. Nature Comm. 2013, 4:1507

(13) Lu, B. Q.; Garcia, N. A.; Chevrier, D. M.; Zhang, P. ; Raiteri, P.; Gale, J. D.; Gebauer, D. ShortRange Structure of Amorphous Calcium Hydrogen Phosphate. Cryst. Growth Des. 2019, 19, $3030-3038$.

(14) Tao, J.; Pan, H.; Wang, J.; Wu, J.; Wang, B.; Xu, X.; Tang, R. Evolution of Amorphous Calcium Phosphate to Hydroxyapatite Probed by Gold Nanoparticles. J. Phys. Chem. C 2008, 112, 14929-14933. 
(15) Ucar, S.; Bjørnøy, S. H.; Bassett, D. C.; Strand, B. L.; Sikorski, P.; Andreassen, J.-P. Formation of Hydroxyapatite via Transformation of Amorphous Calcium Phosphate in the Presence of Alginate Additives. Cryst. Growth Des. 2019, 19, 7077-7087.

(16) Boskey, A. L.; Posner, A. S. Conversion of Amorphous Calcium Phosphate to Microcrystalline Hydroxyapatite. A pH-Dependent, Solution-Mediated, Solid-Solid Conversion. J. Phys. Chem. 1973, 112, 14929-14933.

(17) Ibsen, C. J. S.; Leemreize, H.; Mikladal, B. F.; Skovgaard, J.; Bremholm, M.; Eltzholtz, J. R.; Iversen, B. B.; Birkedal, H. Alkali Counterions Impact Crystallization Kinetics of Apatite Nanocrystals from Amorphous Calcium Phosphate in Water at High pH. Cryst. Growth Des. 2018, $18,6723-6728$.

(18) Jiang, S.; Jin, W.; Wang, Y.-N.; Pan, H.; Sun, Z.; Tang, R. Effect of the aggregation state of amorphous calcium phosphate on hydroxyapatite nucleation kinetics. $R S C A d v ., 2017,7,25497-$ 25503.

(19) Kim, D.; Lee, B.; Thomopoulos, S. Jun, Y.-S. The role of confined collagen geometry in decreasing nucleation energy barriers to intrafibrillar mineralization. Nature Comm. 2018, 9:962

(20) Walton, A. G.; Bodin, A. G.; Furedi, W. J.; Schwartz, A. Nucleation of calcium phosphate from solution. Canadian J. Chem. 1967, 45, 2695-2701.

(21) Terraschke, H.; Rothe, M.; Tsirigoni, A.-M.; Lindenberg, P.; Ruiz Arana, L.; Heidenreich, N.; Bertram, F.; Etter M. In situ luminescence analysis: a new light on monitoring calcium phosphate phase transitions. Inorg. Chem. Front., 2017, 4, 1157-1165. 
(22) Cadez, V. Erceg, I.; Selmani, A.; Jurašin, D. D., Šegota, S.; Lyons, D. M.; Kralj, D.; Sikiric, M. D. Amorphous Calcium Phosphate Formation and Aggregation Process Revealed by Light Scattering Techniques. Crystals 2018, 8, 254

(23) Vecstaudza, J.; Gasik, M.; Locs, J. Amorphous calcium phosphate materials: Formation, structure and thermal behavior. J. Eur. Ceram. Soc. 2019, 39, 1642-1649.

(24) Wang, C.-G.; Liao, J.-W.; Gou, B.-D.; Huang, J.; Tang, R.-K.; Tao, J.-H.; Zhang, T.-L.; Wang, K. Crystallization at Multiple Sites inside Particles of Amorphous Calcium Phosphate. Cryst. Growth Des. 2009, 9, 2620-2626.

(25) Zhang, Q.; Jiang, Y.; Gou, B.-D.; Huang, J.; Gao, Y.-X.; Zhao, J.-T.; Zheng, L.; Zhao, Y.-D.; Zhang, T.-L.; Wang, K. In Situ Detection of Calcium Phosphate Clusters in Solution and Wet Amorphous Phase by Synchrotron X-ray Absorption Near-Edge Spectroscopy at Calcium K-Edge. Cryst. Growth Des. 2015, 15, 2204-2210.

(26) Uskoković, V. Disordering the Disorder as the Route to a Higher Order: Incoherent Crystallization of Calcium Phosphate through Amorphous Precursors. Cryst. Growth Des. 2019, $19,4340-4357$.

(27) Simon, P.; Grüner, D.; Worch, H.; Pompe, W.; Lichte, H.; El Khassawna, T.; Heiss C.; Wenisch, S.; Kniep, R. First evidence of octacalcium phosphate@osteocalcin nanocomplex as skeletal bone component directing collagen triple-helix nanofibril mineralization. Sci. Rep. 2018 $8: 13696$ 
(28) Crane, N. J.; Popescu, V.; Morris, M. D.; Steenhuis, P.; Ignelzi Jr., M. A. Raman spectroscopic evidence for octacalcium phosphate and other transient mineral species deposited during intramembranous mineralization. Bone 2006, 39, 434-442.

(29) Michael W. Swift, M. W.; Chris G. Van de Walle, C. G.; Fisher, M. P. A. Posner molecules: from atomic structure to nuclear spins. Phys. Chem. Chem. Phys., 2018, 20, 12373-12380.

(30) Zeng, C.; Vitale-Sullivan, C.; Ma, X. In Situ Atomic Force Microscopy Studies on Nucleation and Self-Assembly of Biogenic and Bio-Inspired Materials. Minerals 2017, 7, 158; doi:10.3390/min7090158.

(31) Montes-Hernandez, G.; Renard, F. Time-Resolved in Situ Raman Spectroscopy of the Nucleation and Growth of Siderite, Magnesite, and Calcite and Their Precursors. Cryst. Growth Des. 2016, 16, 7218-7230.

(32) Montes-Hernandez, G.; Bah, M. ; Renard, F. Mechanism of formation of engineered magnesite: A useful mineral to mitigate $\mathrm{CO}_{2}$ industrial emissions. J. $\mathrm{CO}_{2}$ Util. 2020, 35, 272-276.

(33) Montes-Hernandez, G.; Renard, F.; Auzende, A.-L.; Findling, N. Amorphous calciummagnesium carbonate (ACMC) accelerates dolomitization at room temperature under abiotic conditions. Cryst. Growth Des. 2020, 20, 1434-1441.

(34) Kazanci, M.; Fratzl, P.; Klaushofer, K.; Paschalis, E. P. Complementary Information on In Vitro Conversion of Amorphous (Precursor) Calcium Phosphate to Hydroxyapatite from Raman Microspectroscopy and Wide-Angle X-Ray Scattering. Calcif. Tissue Int. 2006, 79, 354-359. 
(35) Stammeiera, J. A.; Purgstaller, B.; Hippler, D.; Mavromatisa, V.; Dietzel, M. In situ Raman spectroscopy of amorphous calcium phosphate to crystalline hydroxyapatite transformation. MethodsX 2018, 5, 1241-1250.

(36) Han, B., Louhi-Kultanen, M. Real-Time Raman Monitoring of Calcium Phosphate Precipitation in a Semi-Batch Stirred Crystallizer. Cryst. Growth Des. 2018, 18, 1622-1628.

(37) Yu, M., Wang, L., Zhang, W., Ganss, B. An Evolutionarily Conserved Subdomain in Amelotin Promotes Amorphous Calcium Phosphate-to-Hydroxyapatite Phase Transition. Cryst. Growth Des. 2019, 19, 2104-2113.

(38) Van Kemenade, M. J. J. M., De Bruyn, P. L. A Kinetic Study of Precipitation from Supersaturated Calcium Phosphate Solutions. J. Colloid Interface Sci. 1987, 118, 564-585

(39) Gebauer, D.; Völkel, A.; Cölfen, H. Stable prenucleation calcium carbonate clusters. Science 2008, 322, 1819-1822.

(40) Gebauer, D.; Kellermeier, M.; Gale, J. D.; Bergstrom, L.; Colfen, H. Pre-nucleation clusters as solute precursors in crystallization. Chem. Soc. Rev., 2014, 43, 2348-2371.

(41) Wang, T.; Cölfen, H.; Antonietti, M. Nonclassical crystallization: Mesocrystals and morphology change of $\mathrm{CaCO} 3$ crystals in the presence of a polyelectrolyte additive. J. Am. Chem. Soc. 2005, 127, 3246-3247.

(42) Demichelis, R.; Raiteri, P.; Gale, J. D.; Quigley, D.; Gebauer, D. Stable prenucleation mineral clusters are liquid-like ionic polymers. Nature Comms. 2011, doi: 10/1038/ncomms1604. 
(43) Hamm, L. M.; Giuffre, A. J.; Han, N.; Tao, J.; Wang, D.; De Yoreo, J. J.; Dove, P. M. Reconciling disparate views of template-directed nucleation through measurement of calcite nucleation kinetics and binding energies. PNAS 2014 doi: 10.1073/pnas.1312369111.

(44) $\mathrm{Hu}$ et al. The thermodynamics of calcite nucleation at organic interfaces: Classical vs. nonclassical pathways. Faraday Discuss. 2012, 159, 509-523.

(45) Fritz, B.; Clément, A.; Montes-Hernandez, G.; Noguera, C. Calcite formation by hydrothermal carbonation of portlandite: complementary insights from experiment and simulation. CrystEngComm 2013, 15, 3392-3401. 
Table 1. List of dynamic in situ Raman spectroscopy experiments performed to study the nucleation of brushite and hydroxyapatite. Experiments were performed under three different $\mathrm{pH}$ regimes, equimolar $\mathrm{Ca} / \mathrm{P}$ ratio or hydroxyapatite stochiometric ratio $(\mathrm{Ca} / \mathrm{P}=1.66)$, and two different calcium sources $\left(\mathrm{CaCl}_{2}\right.$ and $\left.\mathrm{Ca}(\mathrm{OH})_{2}\right)$.

\begin{tabular}{|c|c|c|c|c|c|c|}
\hline Expt. & $\begin{array}{l}\text { Temp. } \\
\left({ }^{\circ} \mathbf{C}\right)\end{array}$ & pH regime & $\begin{array}{l}\text { Expt. } \\
\text { duration } \\
\text { (h) }\end{array}$ & $\begin{array}{l}\text { Citric } \\
\text { Acid }\end{array}$ & $\begin{array}{l}\text { Transient phase(s) and } \\
\text { principle Raman peak }\end{array}$ & $\begin{array}{c}\text { Final mineral phase(s) } \\
\text { and principle Raman } \\
\text { peak }\end{array}$ \\
\hline 1 & 25 & from 9.8-to-6.8 & 23 & none & $\begin{array}{l}\text { ACP at } 957 \mathrm{~cm}^{-1} \\
\text { OCP at } 962 \mathrm{~cm}^{-1}\end{array}$ & Brushite at $990 \mathrm{~cm}^{-1}$ \\
\hline 2 & 25 & from 9.8-to-6.8 & 18 & yes & $\begin{array}{l}\text { ACP at } 955 \mathrm{~cm}^{-1} \\
\text { OCP at } 962 \mathrm{~cm}^{-1}\end{array}$ & $\begin{array}{l}\text { Brushite at } 990 \mathrm{~cm}^{-1} \\
\text { Hydroxyapatite at } 963 \mathrm{~cm}^{-1} \\
\text { (minor proportion) }\end{array}$ \\
\hline 3 & 24 & $\mathrm{pH}>12.2$ & 19 & none & $\begin{array}{l}\text { ACP at } 954 \mathrm{~cm}^{-1} \\
\text { ATCP at } 943 \mathrm{~cm}^{-1} \\
\text { OCP at } 961 \mathrm{~cm}^{-1}\end{array}$ & $\begin{array}{l}\text { Hydroxyapatite at } 963 \mathrm{~cm}^{-1} \\
\text { ATCP and OCP (minor } \\
\text { proportions) }\end{array}$ \\
\hline 4 & 25 & $\mathrm{pH}>12.2$ & 20 & yes & $\begin{array}{l}\text { ACP at } 956 \mathrm{~cm}^{-1} \\
\text { ATCP at } 943 \mathrm{~cm}^{-1} \\
\text { OCP at } 961 \mathrm{~cm}^{-1}\end{array}$ & $\begin{array}{l}\text { Hydroxyapatite at } 963 \mathrm{~cm}^{-1} \\
\text { ATCP (significant } \\
\text { proportion) } \\
\text { OCP (minor proportion) }\end{array}$ \\
\hline 5 & 24 & from 12.4 to 11 & 2 & none & $\begin{array}{l}\text { ACP1 at } 951 \mathrm{~cm}^{-1} \\
\text { ACP2 at } 954 \mathrm{~cm}^{-1} \\
\text { OCP at } 959 \mathrm{~cm}^{-1}\end{array}$ & Hydroxyapatite at $962 \mathrm{~cm}^{-1}$ \\
\hline
\end{tabular}



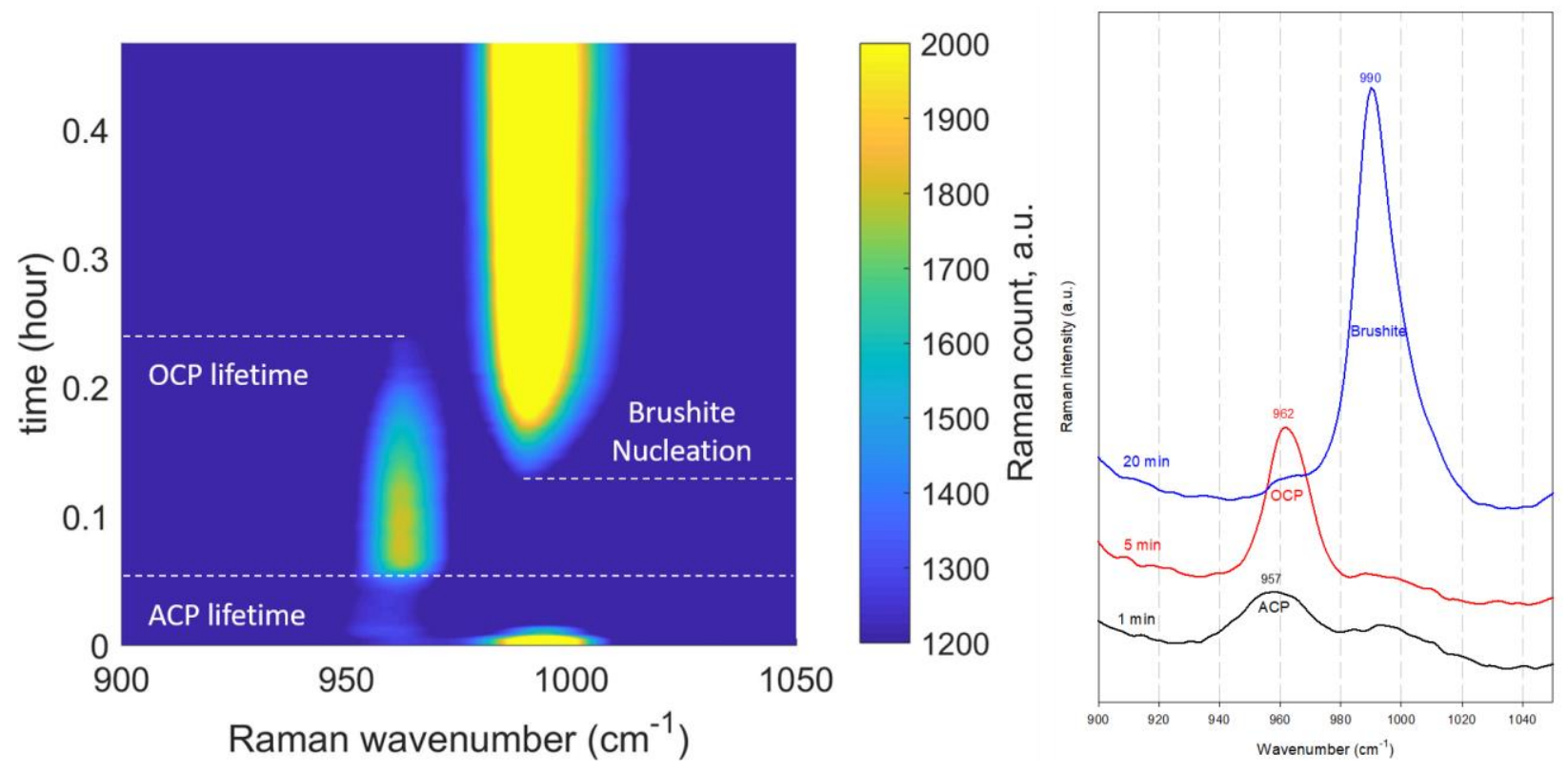

Figure 1. (left) Time-lapse Raman spectroscopy monitoring of the formation of brushite in experiment 1 (Table 1). (right) Main peaks of transient phases (ACP and OCP) and brushite, the most stable phosphate phase under the investigated conditions. 

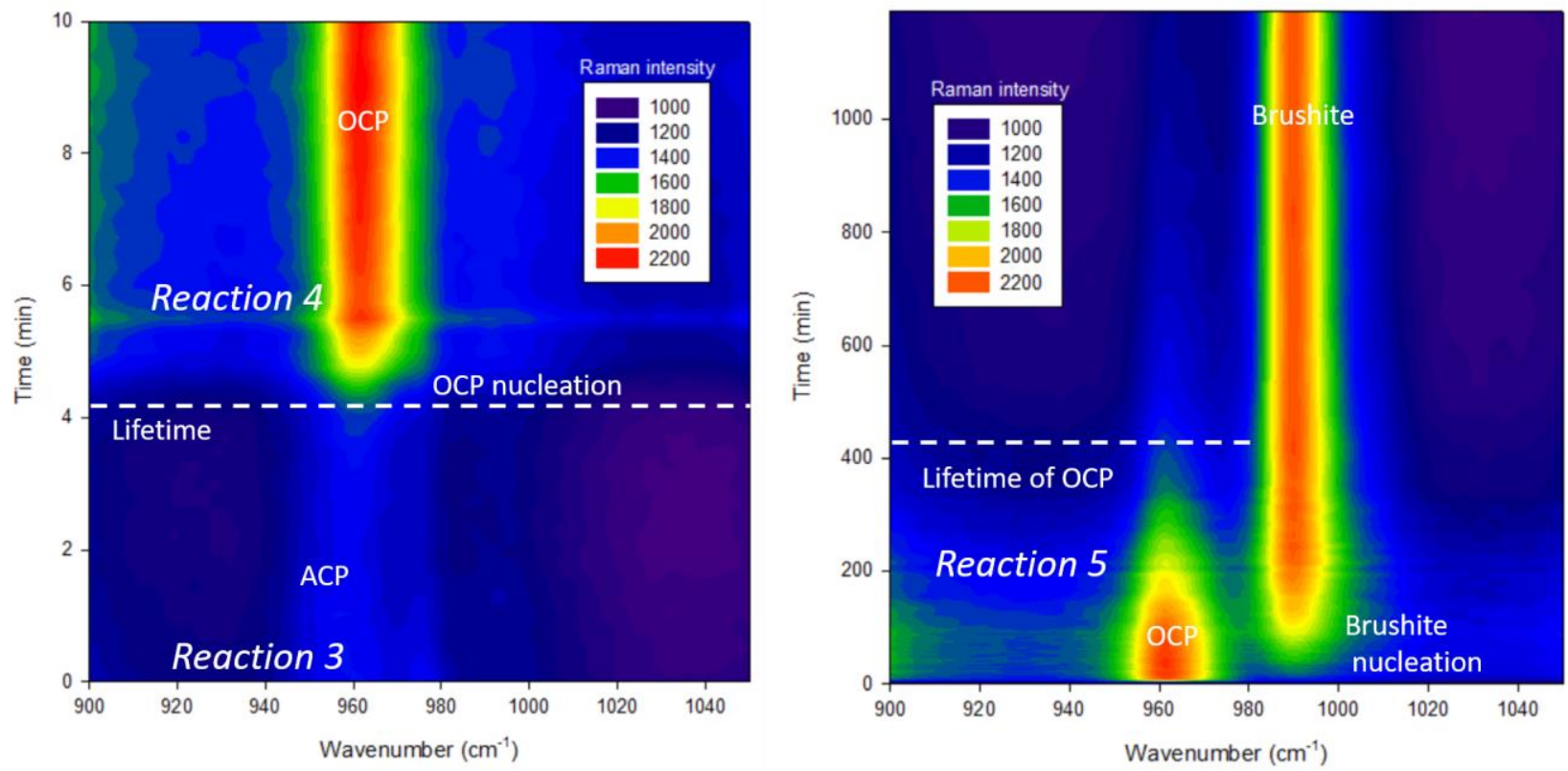

Figure 2. Time-lapse Raman spectroscopy monitoring of the formation of brushite in experiment 2 (Table 1). (left) Raw data Raman spectra between 0 and 10 minutes showing the formation of ACP (reaction 3 in the text) and the nucleation time of OCP (reaction 4 in the text). (right) Raw data Raman spectra from 0 to 1200 minutes showing the transformation of OCP into brushite (reaction 5 in the text). 

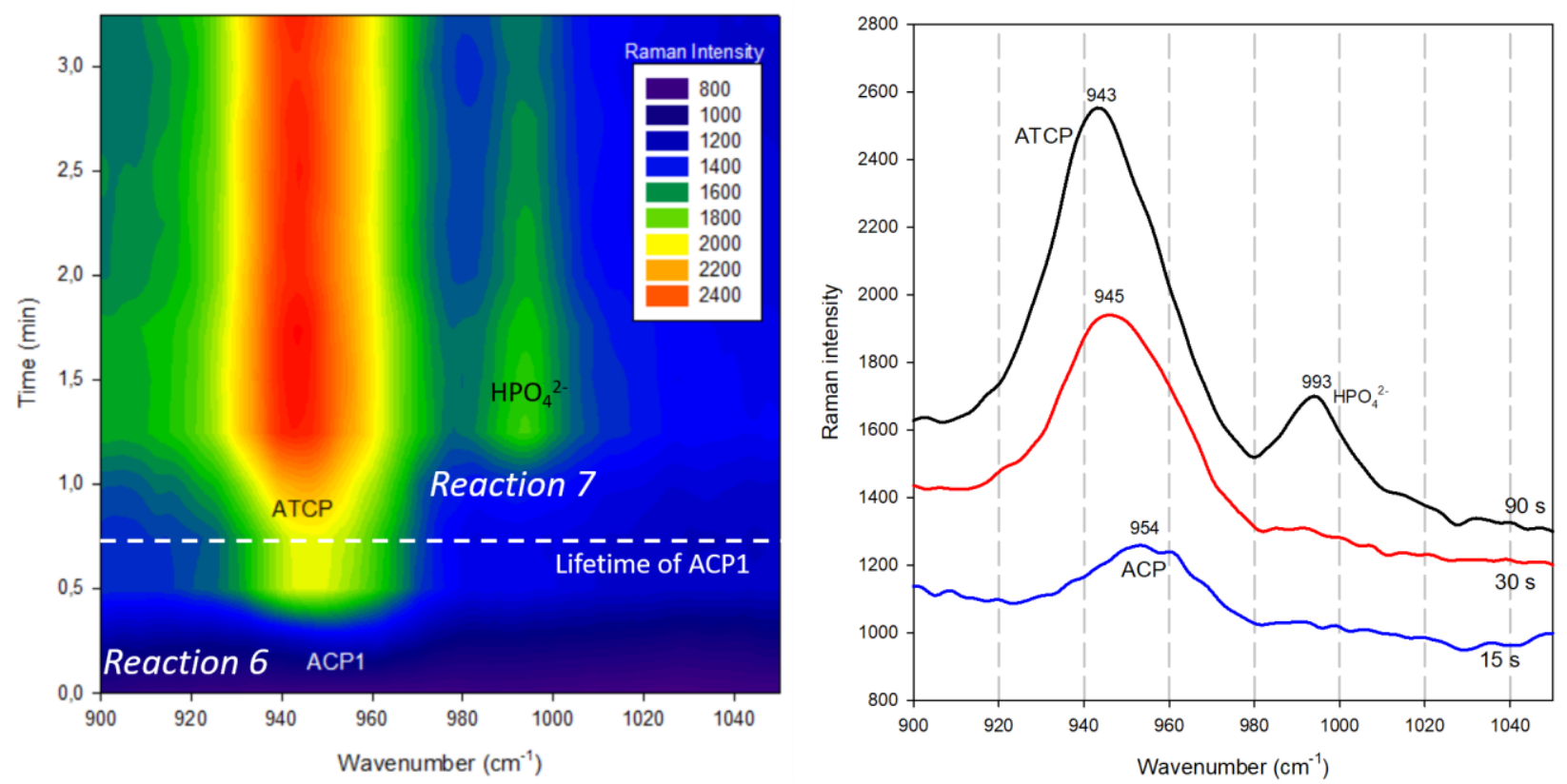

Figure 3. Time-lapse Raman spectroscopy monitoring of the formation of hydroxyapatite (HAp) in experiment 3 (Table 1). (left) Raw data Raman spectra between 0 and 3 minutes indicating the formation of ACP1 (reaction 6 in the text) and the transformation of ACP1 intoATCP (reaction 7 in the text). (right) Three raw data Raman spectra at 15, 30 and 90s showing a fast shift of the position of the Raman peak of amorphous phases from 954 to $943 \mathrm{~cm}^{-1}$. 

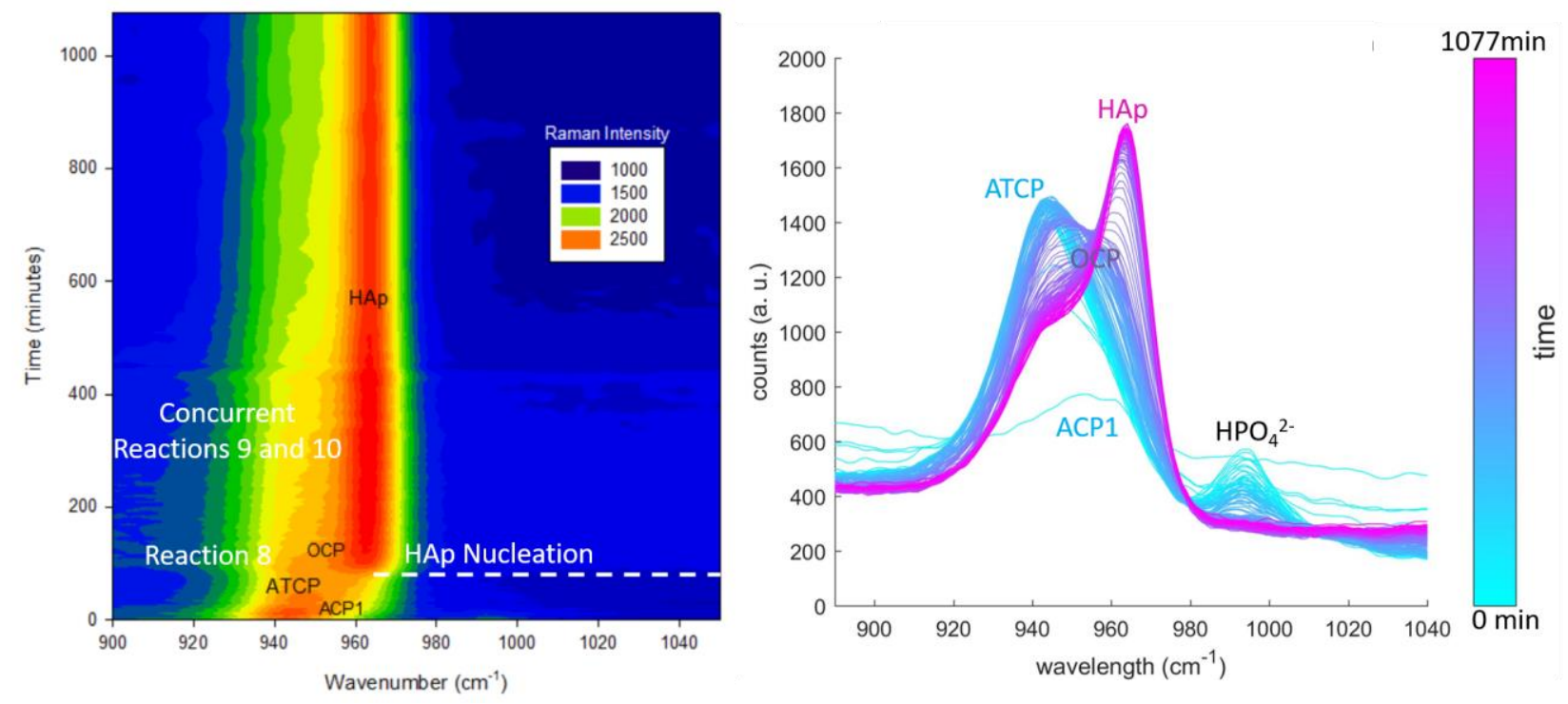

Figure 4. Time-lapse Raman spectroscopy monitoring of the formation of hydroxyapatite (HAp) in experiment 3 (Table 1). (left) Raw data Raman spectra between 0 and 1077 minutes showing the transformation of ATCP into OCP (reaction 8 in the text) and the synchronous transformations of OCP into hydroxyapatite (reaction 9 in the text) and ATCP into hydroxyapatite (reaction 10 in the text). (right) Time-lapse evolution of the main peaks used for deconvolution fitting. 

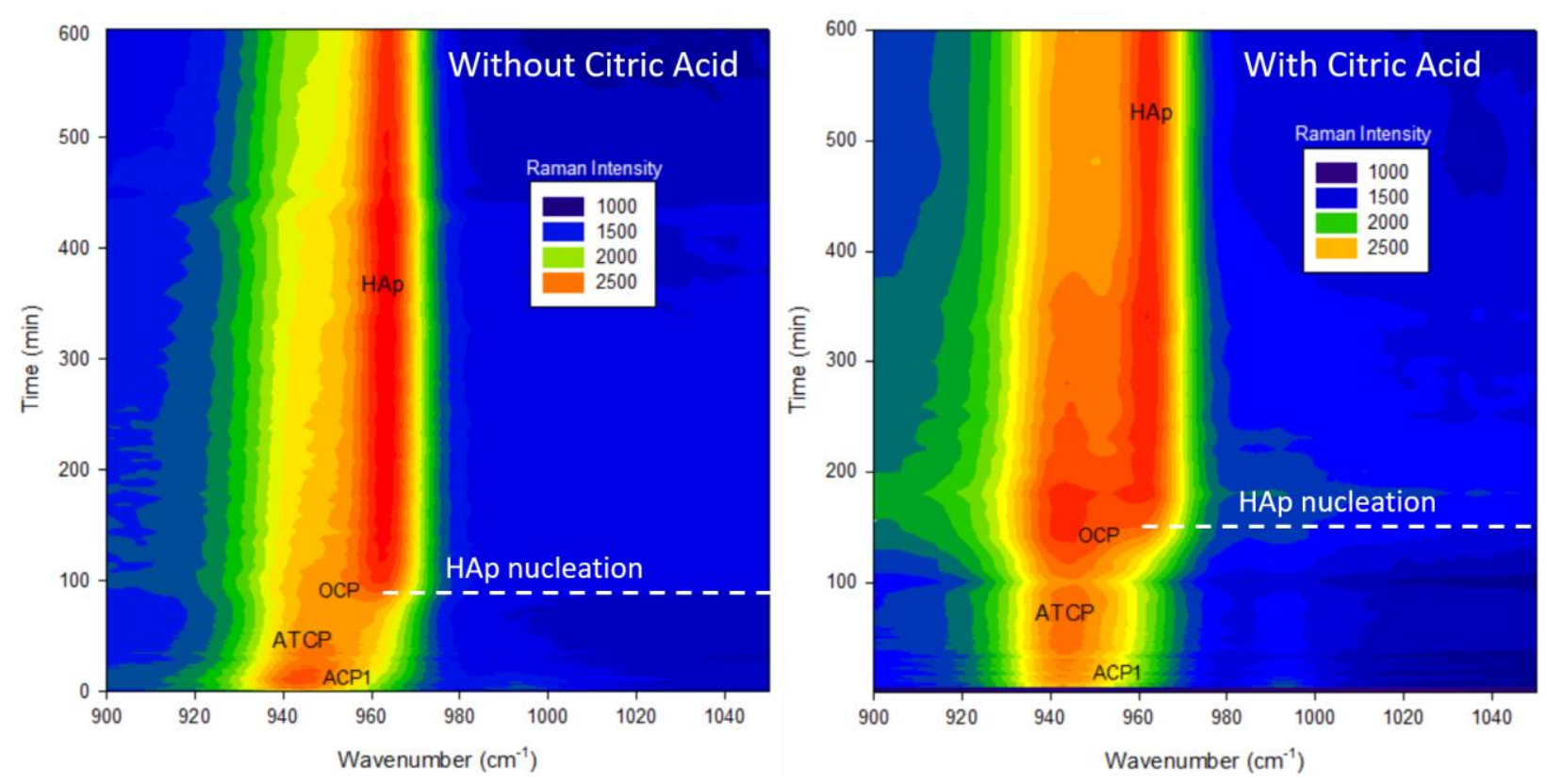

Figure 5. Time-lapse Raman spectroscopy monitoring of the formation of hydroxyapatite (HAp) in experiments 3 and 4 (Table 1). (left) Raw data Raman spectra between 0 and 600 minutes show the main transient calcium phosphate phases detected during hydroxyapatite formation in experiment 3. The reaction mechanism is summarized by reactions 6 to 10 in the text. (right) Raw data Raman spectra between 0 and 600 minutes showing the main transient calcium phosphate phases detected during hydroxyapatite formation in experiment 4 in presence of citric acid. The reaction mechanism is very similar than without citric acid; however, a significant retarding effect is measured as indicated by the difference of hydroxyapatite nucleation time with and without citric acid. 

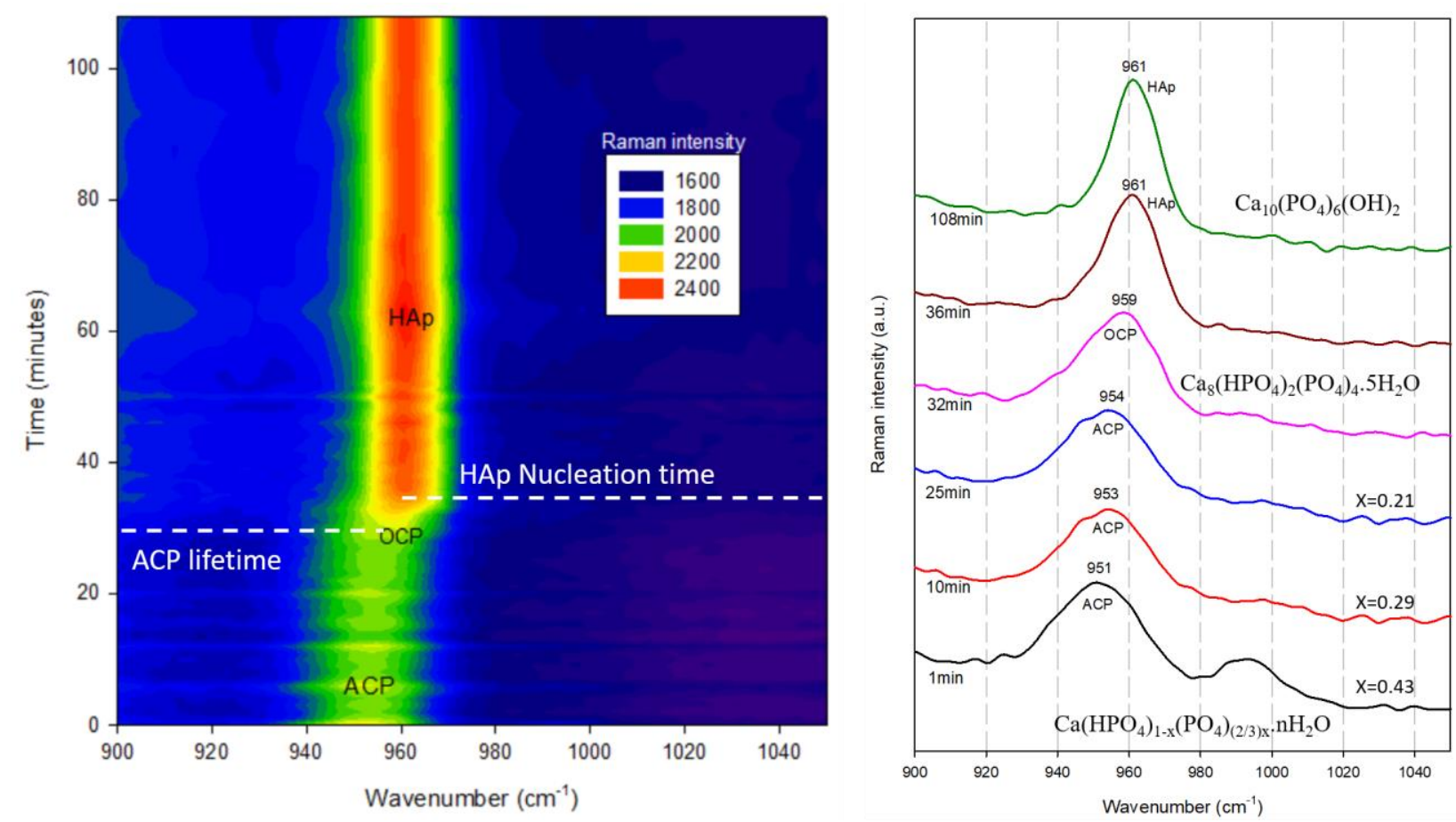

Figure 6. Time-lapse Raman spectroscopy monitoring of the formation of hydroxyapatite (HAp) in experiment 5 (Table 1). (left) Raw data Raman spectra between 0 and 108 minutes indicating the lifetime of ACP and nucleation time of hydroxyapatite. (right) Six raw data Raman spectra at $1,10,25,32,36$ and 108 minutes showing the signatures of ACP, OCP and hydroxyapatite. As presented in Figure S9, phosphate content, $x$, was calculated using a linear interpolation $(x=68.357$ - $(1 / 14)^{*} \mathrm{P}_{\mathrm{ACP}}$ : where $\mathrm{P}_{\mathrm{ACP}}$ is the position of the Raman peak in $\mathrm{cm}^{-1}$ comprised between 943 and 957). 